\title{
OFFICIAL REPORTS
}

\author{
IN CELRGH OS \\ MISS MARY E. THORNTON,
} 500 West One Hundred and Twenty-Grst Street, New York City

\section{Pry}

[Contributon are requested to write only on one side of the paper and to be careful to have names of people and places very plainly written and correctly spelled. When material can be type-written it is greatly appreclated by the editor.

Material for this department shouid be in the hands of Miss Thornton before the fifteenth of the month, and last items and very brief annonncements must reach the Editor-in-Chief at Rochester not later than the twentieth of the month preceding the date of issue.-ED.]

\section{NEW YORK STATE MEETING}

ONLY a very brief account of the semi-annual meeting of the New York State Nurses' Association, held in New York on October 18, will be attempted this month, but details will be given in the next issue of the JourNaI.

The morning session was opened fairly promptly by the president, Miss Damer, and the business of the day was in order. After the presentation of the reports of the standing committees and the acceptance of the onc individual resignation, the invitations of the Alumnæ Association of St. Luke's Hospital Alumne of the delegates and officcrs to luncheon at the Manhattan Hotel, afternoon tea at close of convention to all present by the Alumne Association of Bellevue, and a reception by the Alumnæ Association of Mt. Sinai on the afternoon of the 19th were announced. The continuation of the revision of the bylaws followed. Article II., on Eligibility for Membership in the society, individual and organization, is given in full here, and the revised by-laws when printed will be mailed to the members.

\section{AR'TICLE II.}

\section{ELIOIBILITY.}

Individual Membership.

SEctror 1. Only sucb resident nurses of the State of New York who sball have received from the Regents of the University of the State of New York a certificate of his or her qualifications to practise as a registered nurse shall be eligible to individual membership in the New York State Nurses' Association, provided said applicants be acceptable to the association.

Individual members shall organize when they shall have reached twenty-five members in a community.

Applicants eligible for membership in any organization belonging to the New York State Nurges' Association shall not be admitted to the association as individual members.

\section{Organization Membership.}

Only those alumnæ associations wbose members are graduates from training-schools registered by the Regents of the State of New York as maintaining proper standards sball be eligible to membership in the New York State Nurses' Association, provided such organization be acceptable to the association.

Other organizations shall be eligible for membership provided all member 126 
admitted after October, 1904, hold certificates of registration and provided such organizations be acceptable to the association.

\section{Applications.}

Src. 2. The applications of individuals and of organizations shall be made in writing to the chairman of the Committee on Credentials one month before the regular meetings at which those approved by the aforesaid committee shall be voted upon by the association.

$$
\text { of Individuals. }
$$

Applications of individuals shall be accompanied by the full name and address, the name of school and date of graduation, the number and date of certificate of registration, and shall be endorsed by two members of the association. The annual dues must accompany the applications.

\section{Of Organizations.}

Applications of organizations shall be signed by the president and secretary of such organizations and accompanied by a copy of their constitution and bylaws, a list of members, with dates and numbers of certificates of registration held by members admitted after October, 1904.

The annual dues must accompany the application.

\section{Voting.}

Src. 3. Officers, charter members, individual members, and duly accredited delegates only shall be entitled to vote.

Members of organizations belonging to the New York State Nurses' Association may be present at regular and annual meetings, may take part in discussions upon all measures brought forward, but unless otherwise entitled shall not introduce motions or vote.

\section{Delegates.}

Organizations belonging to the association may send delegates in the pro. portion of one to every ten members, who are resident in the State of New York, and may cast votes in proportion of one to every ten members resident in the State of New York. Such delegates sliall bring from the secretaries of their organizations letters of credentials which shall be presented to the secretary of the New York State Nurses' Association before the meeting.

The delegates actually present may deposit the whole number of votes to which their organization is entitled, but no delegate shall cast more than ten votes. The vote of individuals shall be cast in person.

Such members as vote as individuals shall not be included in the estimate of votes entitled to be cast by organizations.

Members or organizations in arrears for one year shall not be entitled to the privileges of the association.

The remainder of the morning and part of the afternoon was devoted to discussion and action on the revisions suggested, and finally the work was finished early in the afternoon session.

Miss S. F. Palmer read an elaborate and carefully prepared report, submitted by the secretary of the Board of Nurse Examiners, Miss Hitchcock, which will be published in full later. After reading this report many will understand the delay in receiving their certificates of registration from Albany.

The associatlon then had the pleasure of hearing most entertaining and interesting remarks on the "Social Side of the Modern Treatment of Tuberculesis," by Dr. J. A. Miller and Mr. Christopher Easton, and these remarks were followed up by short addresses from nurses who are engaged in the work of the new movement of the care of tuberculosis patients in their own homes. It was decided that no further steps with regard to badges would be taken until more of our members were registered nurses. 
The subject of affiliation with the Associated Alumnx of the United States was discussed, and the pleasure was to become affiliated without further delay.

After the election of the new nembers of the Nominating Committee the mecting was adjourned to mcet in Albany in April, 1905.

Both morning and afternoon sessions were largely attended. The hospitality of the Alumnæ Associations of Bellevue and St. Luke's was much enjoyed and appreciated, and many were looking forward to visiting new Mt. Sinai the next afternoon.

Margaret Sutherland, Secretary.

\section{CLASS REPORT, HOSPITAL ECONOMICS.}

Tre Class in Hospital Economics is already fairly launched in college life and deeply interested in the various courses.

Besides the opportunity of studying in a scientific manner the subjects with which we arc already superficially familiar, new and varied interests are constantly developing. Among other things we had the pleasure of hearing Dr. Davidson, the Archbishop of Canterbury, at the time Columbia conferred upon him the degree of Doctor of Laws.

The dormitory life of the students is very pleasant, receptions and fudge parties bringing the students together.

The Phillips Brooks Guild and the IIome Economics Club give us opportunities of social intercourse with students in other departments.

Miss Hawley, Dcan Russell's secretary, conducts Saturday afternoon excursions to various places of interest about the city. These excursions are frce to all students. Last Saturday the Hall of Fame at the New York University was visited.

Our own excursions began Friday afternoon, October 7 , with a visit to Bellevue Hospital. It was of especial interest as being the hospital where the first training-school for nurses in the United States was organized. The superintendent of nurses, Miss Delano, conducted us through the different departments and instructed the class in some of the methods of carrying on the business of a large city institution.

In the tuberculosis clinic we met Miss Damar, who told us something about her work in that line.

A cosey tea in Miss Delano's room finished a delightful afternoon. BERTHA M. HAMMOND, 1230 Amsterdam Avenue, New York City.

October 17, 1904.

\section{THE COURSE IN HOSPITAL ECONOMICS}

Mrss Anna L. Atcine, instructor in charge of the special hospital economics students at Teachers College, reports the registration of the following eight students, with one other student to follow who will make up her work later: Miss B. Hammond, Miss I. Tracy, Miss G. Watson, Miss S. Parsons, Mrs. L. M. Wright, Miss Van Horne, Miss J. Macconachie, Miss M. D. Jamison, Miss E. Ambrose (November 1).

Miss Alline reports that the work has begun in a very promising way, but there is, of course, no account to give of work this month, as at the date of going to press the students have only been matriculated for two weeks. 
The following subscriptions have been received during September and October, but were received too late for report in the October JournaL. Our finances are, unfortunately, still in bad shape, and need all the interest which can be aroused by our friends.

Sept. 14, Miss E. J. Keating ................\$2 00

Sept. 27, Miss A. H. Patterson, through Miss Nutting... 500

Sept. 27, Miss A. A. Chesley................. 200

Oct. 1, Miss J. Schmidt, through Miss Stowe...... 300

Oct. 1, Miss A. E. Bolton................ 300

Oct. 1, Miss E. I. Horton................ 300

Oct. 1, Miss E. L. Stowe.................. 5 00

Oct. 1, Miss Frances Black ................ 1000

Oct. 1, Miss B. F. M................... 200

Oct. 1, Mrs. M. A. Moore................ 400

Oct. 1 , Mrs. Marie MeNally ................. 500

Oct. 1 , Miss C. J. Milne.................. 500

Oet. 1, Miss M. A. Dunlop................. 200

Oct. 1, Miss DeWitt, through Miss MeIsaac....... 200

Oct. 1, A Friend, through Miss Alline........... 2500

Miss Mary Humphrics, through Miss Maxwell. 500

From the following members of the Rochester Homøopathic Hospital Alum. næ Association, Rochester, N. Y.:

Miss Mary E. Wood $\ldots \ldots \ldots \ldots \ldots \ldots \ldots \ldots \ldots \ldots \ldots \$ 300$

Miss Elizabeth Webber $\ldots \ldots \ldots \ldots \ldots \ldots \ldots \ldots \ldots \ldots, 300$

Miss Gertrude Hincher .................. 300

Miss Ida J. Anderson ................... 300

Miss Estelle Meyer .................... 200

Miss Jessica Heal ........................ 3 00

Miss Violet Heal ....................... 200

Miss Emily Diehle ..................... 300

Miss Emily Jones ..................... 300

Mrs. Jessie Parsons ..................... 300

\section{REGULAR MEETINGS}

Rochester.-The Rochester City Hospital Alumnæ held their annual meeting and election of officers at the Isabella Hart Memorial Home on Tuesday, October 11, at which the following officers were elccted: President, J. M. Wilson; first vice-president, M. M. McLaren; second vice-president, Mae Connor; corresponding secretary, Lydia Brown, 158 South Fitzhugh Street, Rochester, N. Y.; recording secretary, Marie Phelan, and treasurer, Emma Knowles, 67 Edinburgh Street, Rochester, N. Y. Annie E. Kennedy was chosen as delegate to attend the New York State Nurses' Association. The question of an independent directory was brought before the association, and after a lengthy discussion it was decided to let the directory continue under its present management. The association was pleased to listen to a short talk by Miss S. F. Palmer in regard to the endowment of a chair of hospital economics at Columbia College. Miss Palmer asked that each nurse give one day's work towards the support of the course. 
A committee was appointed to receive any contributions, and it is hoped the nurses will respond liberally.

BrookLyn.-The regular monthly mceting of the Long Island College Hospital Alumnæ Association was held at the Registry on Tuesday, October 11, when there was a very large attendance. The president, Miss Anna Davids, was in the chair. After the usual reports had been read, it was stated by Miss Charlotte Arnold, treasurer of the fund being raised for repayment of the debt incurred in furnishing the Registry, that contributions had been handed in by Misses Fraser, Wenstrom, E. Hall, and Roeberg, and also that several others are working in different ways for the accomplishment of the same object. It was stated that a euchre would be held at the Registry once a month, the proceeds of which would be given to the same fund. At the close of the business the members were regaled with coffee and cake and a quiet social talk. This was followed by a deeply interesting and profitable address by Dr. Delatour on etherization and sterilization, for which the members tendered him a very cordial vote of thanks.

Puinaderphu.-The regular meeting of the Nurses' Alumnæ of the Hospital of the Protestant Episcopal Church was held on October 4, 1904, in the Nurses' Home. The meeting was called to order by Miss Haines, president. The minutes of the June meeting were accepted as read and the usual routine business transacted. In the way of new business it was voted to engage a lecturer to give two or three lectures on parliamentary law. The Misses Nedwill, Shaw, and Howard were appointed a committce to find a suitable lecturer and report at the next meeting. Miss Payne, honorary president, gave some useful information in regard to Statc registration and the work of the Graduate Nurses' Association of the State of Pennsylvania. Miss Haines, president, urged all our nurses to attend the sessions of the annual meeting of the Graduate Nurses' Association, to be held October 26,27 , and 28 in Philadelphia. The meeting then adjourned to meet next month in the Church House.

BatTimore.-The third quarterly meeting of the University of Maryland Nurses' Alumnæe was held at the hospital on September 5 at three P.M. Roll-call showed a good number present. At the June meeting a committee of five was appointed to collect individual subscriptions to make it possible for the alumnæ to purchase a share in the stock of Tife American Journal of Nursing. It is earnestly hoped and expected that all members will take pleasure in responding to the call of their alumnæ by sending in subscription asked for as soon as possible. A committee of five was appointed to arrange for a course of lectures to be held under the auspices of the alumnæ during the coming winter and spring. The meeting was full of interest and much business was transacted, after which it adjourned to meet again, "D. V.," on the first Monday in December.

Crrcissatr.-The regular meeting of the Jewish Hospital Alumno Association of Cincinnati, O., was held at the Jewish Hospital on Friday, October 14. Nine members were present. After a short business meeting Dr. Alfred Friedr lander gave an interesting talk on the United Jewish Charities and its work in Cincinnati. The meeting then adjourned to meet again the second Thursday in December. The following programme has been prepared for the winter's work: 
for October, “The United Jewish Charities," Dr. Alfred Friedlander, momber of Board of Directors; for December, "The Progress of State Registration," Miss Francis Adler; for February, "The Public Library," Dr. Henry Wald Bettman, president of Library Board; for April, "Course in Hospital Economics at Teachers College, Columbia University," Miss Florence Williams; for May, business meeting.

New YoRk.-The regular meeting of the New York City Training-School Alumnæ was held in the Academy of Medicine, October 11, 1904, at three P.M., Miss J. Amanda Silver in the ehair. Dr. Edward S. Peck, of the Board of Examiners of the Training-School, gave an interesting lecture on the eye, ear, and throat. Besides the usual routine business much interest was shown in selecting nurses as delegates for the meetings of the county and State associations. The members were saddened by the announcement of the sudden death of Mrs. Isabel Corlett Armstrong, of the Class of 1895, who died September 17, 1904, at Greenwich, Conn. A very dainty luncheon was given in the banquet hall by Miss Elizabeth Farrell.

Phinaderphu.-The quarterly meeting of the Alumne of the Polyclinic Hospital was held October 7, at three P.M., at the Kay House. In the absence of the president and vice-president, Miss Banfield presided. The usual business was transacted. Three new members were admitted. One application for membership was received. An announcement was read of the annual meeting of the Pennsylvania State Nurses' Association, which is to be held in Philadelphia on October 26,27 , and 28 . The members were requested to attend all the sessíons. The meeting adjourncd at four P.M., after which refreshments were served.

Montreal.-The annual meeting of the Canadian Nurses' Association was held in Montreal on October 16. The association now numbers two hundred and the year's work has been very satisfactory. Officers were elected as follows: For president, Miss Colquhoun; vice-president, Miss Dunlop; corresponding secretary, Miss Collie; recording secretary, Miss Des Brisay; treasurer, Miss Cooper; committee, Miss Hill, Miss E. Cooper, Miss Bulloch, Miss MacBride. The Reading-Room of the association is at 169 Peel Street, in Tooke's Block, where the latest nursing literature may be found.

Rochester.-The Monroe County Registered Nurses' Association held a regular meeting on the last Tuesday in September. The society has ninety paid up members. One subject of interest discussed was a club-room, and a committee was appointed to investigate. A special meeting will be called when the committee is ready to report. The Course in Hospital Economics was presented by Miss Balcum, and Miss S. F. Palmer and Miss Ida R. Palmer also spoke on this subject.

Providerce.-The first regular meeting of the Rhode Island Hospital Alumnæ was held on Tuesday, October 11, in the Nurses' Home. The members present spoke informally on State registration, and a beginning has been made by calling a mass meeting of nurses, to be held October 19 in the Young Men's Christian Association Hall, inviting all graduate nurses resident in the State to be present. 
Erratum, October issue: For the address of the secretary of the New York State Nurses' Association, read 219 West Eighty-third Street, New York City.

\section{MARRIAGES}

Is St. Louis, Mo., on September 26, Mrs. Sabina Page Pemberton, graduate of St. Luke's Hospital, New York, Class of 1894, and late superintendent of the Pasadena Hospital, Cal., to Colonel Charles Morton, Seventh United States Cavalry. Colonel and Mrs. Morton are stationed at Fort Meyer, Va.

Miss Alice M. Richalio, a graduate of the Protestant Episcopal Hospital Training-School for Nurses, of Philadclphia, Class of 1899, was married in June to Mr. James H. Larrimer. Mr. and Mrs. Larrimer will reside in Philadelphia.

Aт Picton, Ontario, on September 28, 1904, Miss Elizabeth Widdifield, Toronto General graduate, to Mr. John W. Kearney. At home 7 East Eighty-seventh Street, New York.

Miss M. K. MasseY, Class of 1902, of the University of Maryland, was married on October 5 at her hoine, Sandy Spring, Md., to Dr. Nathan Winslow, of Baltimore, Md.

AT her home, St. Thomas, Ontario, on August 1, 1904, Miss Ida Catherine Anderson, graduate of the Toronto General Hospital, to Mr. William Archibald Porter Wood.

Miss M. A. Fendale, Class of 1901, of the University of Maryland, was married in June at her home, Towson, Md., to Mr. Whelan Cushing, of Balti. more, $\mathrm{Md}$.

Is San Francisco, Cal., September 6, 1904, Mrs. Emilyn Patterson Mann (Army Nurse Corps) to Mr. Clarles Speneer MacArthur.

\section{OBITUARY}

Whereas, An All-Wise Providenec las removed from this earthly life our friend, Mrs. Marion H. Laurance, late supcrintendent of Rex Hospital; and

Whereas, We, the Medical Board of Rex Hospital, do especially and most keenly feel her loss; therefore

Resolved, That by ler death Rex Hospital has becn deprived of an offieer who was faithful in the diselarge of all her duties, economical in the administration of its affairs, and most successful in the executive management of the institution.

Resolved, That we desire to express our sense of a personal loss and bereavement in the death of so capable and gifted a woman.

Resolved, That we tender to the family and friends of the deceased our sin. cere and heartfelt sympathy.

Resolved, That these resolutions be spread upon the minutes of the Medical Board of Rex Hospital, be published in the daily papers of this eity, and that a copy of them be transmitted to her relatives in England and to her friends in this country.

H. A. Royster, M.D.,

H. MCKEE TuCKER, M.D., William deBerniere MacNider, M.D., A. W. KNox, M.D., Chairman. 